\title{
Distribution of one-minute rain rate in Malaysia derived from TRMM satellite data
}

\author{
T. V. Omotosho ${ }^{1,2,3}$, J. S Mandeep ${ }^{2,3}$, M. Abdullah ${ }^{2,3}$, and A. T. Adedijii ${ }^{2,4}$ \\ ${ }^{1}$ Department of Physics, College of Science and Technology Covenant University PMB 1023 Ota, Ogun state, Nigeria \\ ${ }^{2}$ Institute of Space Science, Universiti Kebangsaan Malaysia, 43600 UKM, Bangi, Malaysia \\ ${ }^{3}$ Department of Electrical, Electronic and System Engineering, Faculty of Engineering \& Built Environment, \\ Universiti Kebangsaan Malaysia, 43600 UKM, Bangi, Malaysia \\ ${ }^{4}$ Department of Physics Federal University of Technology, Akure Ondo State, Nigeria
}

Correspondence to: T. V. Omotosho (tomotosho@ covenantuniversity.com)

Received: 31 January 2013 - Revised: 13 August 2013 - Accepted: 21 October 2013 - Published: 19 November 2013

\begin{abstract}
Total rainfall accumulation, as well as convective and stratiform rainfall rate data from the Tropical Rainfall Measuring Mission (TRMM) satellite sensors have been used to derive the thunderstorm ratio and one-minute rainfall rates, $R_{0.01}$, for 57 stations in Malaysia for exceedance probabilities of $0.001-1 \%$ for an average year, for the period 19982010. The results of the rain accumulations from the TRMM satellite were validated with the data collected from different ground data sources from the National Oceanic and Atmospheric Administration (NOAA) global summary of the day (1949-2010), Global Precipitation Climatology Centre (GPCC) (1986-2010), and NASA (1950-1999). The correlation coefficient and the average bias error between TRMM and GPCC for Malaysia were found to be $0.79-0.89$ and $\pm 50 \mathrm{~mm}$, respectively. The deduced one-minute rainfall rates correlated fairly well with those obtained from the previous work carried out in Malaysia, with correlation coefficients of 0.7 in all the 57 locations. The inferred mean annual oneminute rainfall rates were found to be highest in the eastern Malaysia, with values between 84.7 and $153.9 \mathrm{~mm} \mathrm{~h}^{-1}$ for $0.01 \%$ exceedance, and in western Malaysia with values between 81.8 and $143.8 \mathrm{~mm} \mathrm{~h}^{-1}$. The present results will be useful for satellite rain attenuation modeling in tropical and subtropical stations around the world.
\end{abstract}

Keywords. Hydrology (Precipitation)

\section{Introduction}

There is the need for reliable rainfall rate data for planning and designing of satellite communications systems, management of water resources, agricultural purpose, and flooding, as well as to assess the impact of climate change. Rain gauge measurement networks are not as dense or evenly spaced in Malaysia as in other countries, such as the USA, Europe, and Japan. Therefore, satellite observation of rainfall networks may be the best solution for adequate temporal and spatial coverage of rainfall. Satellite-based precipitation data can provide very high temporal (3-hourly) and spatial $\left(0.25^{\circ}\right.$ latitude by $0.25^{\circ}$ longitude grid size) resolutions. Nevertheless, the measurement approach will always lead to a bias in the data (not necessarily large mean error) as well as a random variation of the mean (the stochastic error), and needs to be adjusted to in situ observations (Barrett et al., 1994; Huffman, 1997; Rudolf et al., 1994; Tanvir et al., 2012; Ojo and Omotosho, 2013). In essence, ground-truth data are needed to calibrate space-borne sensors. Satellites have biases and random errors that are caused by factors, such as the sampling frequency, diurnal cycle of rainfall, non-uniform field of view of sensors, and uncertainties in the rain retrieval algorithms (Bell et al., 1990; Kousky, 1980; Kummerow, 1998; Anagnostou et al., 1999a, b; Chiu et al., 1990, 1999; Chang and Chiu, 1999). In general, although rain gauge observations yield relatively accurate point measurements of precipitation, they also suffer from sampling error when representing areal means. They are not available over most oceanic and undeveloped land areas (Xie and Arkin, 1995, 1996; 
Omotosho and Oluwafemi, 2009). The Tropical Rainfall Measuring Mission (TRMM), an American-Japanese earth satellite observation mission (launched in November 1997 and placed at an altitude of $350 \mathrm{~km}$ ), was established to provide a better understanding of the precipitation structure and heating in the tropical regions of the earth (Simpson et al., 1996). Operating in a non-sun-synchronous orbit, it has an orbital period of $91 \mathrm{~min}$, making 16 orbits per day, to provide a good coverage of the tropics. TRMM's onboard instruments include the Precipitation Radar (PR), Microwave Imager (TMI), Visible and Infrared Scanner (VIRS), Cloud and Earth's Radiant Energy System, and Lightning Imaging Sensor. Of these, probably the most prominent is the PR. At the launching stage, TRMM PR was the first space-borne radar that was designed to capture a more comprehensive structure of rainfall than any of the earlier space-borne sensors. It has been producing 3-D rainfall data from space in a manner unprecedented by any previous scientific spacecraft. Today, the TRMM project has about 12 Ground Validation (GV) sites around the world to support its satellite-derived products. Validation sites include Darwin, Australia; Melbourne, Florida; Houston, Texas; Kwajalein Atoll, Republic of the Marshall Islands; Tel Aviv, Israel; Sao Paolo, Brazil; Guam, Marianas Islands; Kaohsiung, Taiwan; Om Koi, Thailand; and two multi-radar sites in Florida and Texas (TRMM Satellite Validation Office) (TRMM, 2011). The GV sites for TRMM data in Asia are: Kaohsiung, Taiwan $\left(22^{\circ} 38^{\prime} \mathrm{N}\right.$, $\left.120^{\circ} 16^{\prime} \mathrm{E}\right)$ and $\mathrm{Om}$ Koi, Thailand $\left(17^{\circ} 48^{\prime} \mathrm{N}, 98^{\circ} 22^{\prime} \mathrm{E}\right)$.

The main objective of this paper is to report one-minute rainfall rates (for exceedance probabilities of $0.001-1 \%$ of an average year) derived from $13 \mathrm{yr}$ data from the TRMM satellite, for use in predicting the impact of rain on radiowave signals on earth-space paths in Malaysia, and to compare these with in situ ground data, the one predicted by International Telecommunication Union Radiowave propagation databases (ITU_RP) and other works done for western Malaysia from 1993 to 2009. Two TRMM satellite data sets (from 1998 to 2010) were used to retrieve convective and stratiform rainfall accumulation to compute thunderstorm ratio over some 57 locations in Malaysia (TRMM, 2013a). These were validated with long-term (ground) rainfall data retrieved from the National Oceanic and Atmospheric Administration (NOAA) website.

\section{Data source (rainfall archives)}

Data for 10 stations out of the 57 locations were obtained from 1949 to 2010. Figure 1 shows the map of Malaysia, and Table 1 lists the names of the 57 locations and asterisks show the 11 stations with long-term $(60 \mathrm{yr})$ ground data. The TRMM data from TRMM website (2013a) were used. They included:

a. Monthly TMI rain product (3A12 V6) containing surface, convective, and stratiform rain rates in $\mathrm{mm} \mathrm{h}^{-1}$

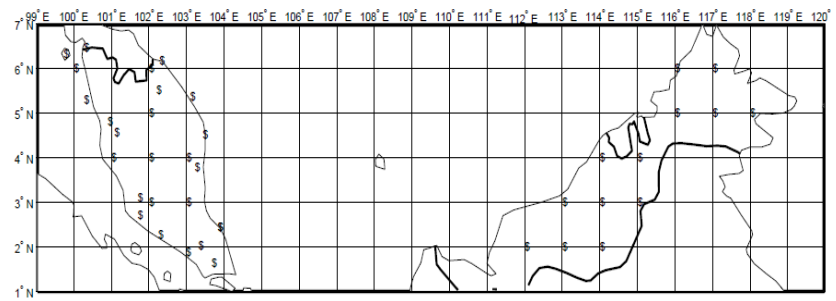

Fig. 1. Map of Malaysia showing some of the stations (\$) used in the study.

at $0.5^{\circ}$ latitude $(\approx 50 \mathrm{~km})$ by $0.5^{\circ}$ longitude $(\approx 50 \mathrm{~km})$ grid size. As it applies to TRMM satellite, stratiform rain is a widespread continuous precipitation produced by large-scale ascent due to frontal or topographic lifting or large-scale horizontal air convergence caused by other means, while convective rain is a localized, rapidly changing, showery precipitation produced by cumulus-scale convection in an unstable air. The third type comprises all rains that are not included in these two categories.

When bright bands do exist, the rain is classified stratiform. When bright bands do not exist, but any value of reflectivity $Z$ along the range exceeds a predetermined value, the rain is classified as convective. When the bright bands do not exist and all the values of $Z$ along the range are less than the predetermined value, then the rain is classified as others (Nirala and Cracknell, 2002).

b. Monthly TRMM and other satellite data sources. Rainfall estimate (3B43 V6) is one of the operational products of TRMM based on rain gauge measurements and satellite estimates of rainfall. The algorithm was developed by the TRMM science team, and the data were processed by the TRMM science data and information system. The gridded estimates are on a temporal resolution of $0.5^{\circ}$ latitude by $0.5^{\circ}$ longitude spacing. The combined data set is based on the concepts developed earlier (Huffman et al., 1995). The TRMM best estimates method is a combination of data from the TMI, PR, and VIRS with SSM/I, IR, and rain gauge data.

c. A number of other Level 3 climate rainfall products for the period from December of 1997 through the present are produced from data collected by the Tropical Rainfall Measuring Mission (TRMM) satellite. They are 3A25, 3A11, 3B31,3B42, 3G68 and 3G68 Land; for more information about the use of these products see the reference (TRMM website 2, 2013b). 
Table 1. List of the 57 Stations in Malaysia used for the study of one-minute rainfall rate.

\begin{tabular}{|c|c|c|c|c|c|c|c|}
\hline & STATION NAME & $\operatorname{LAT}\left(^{\circ}\right)$ & $\operatorname{LON}\left({ }^{\circ}\right)$ & $\operatorname{ELEV}(\mathrm{M})$ & BEGIN & END & Data Period \\
\hline 1 & LANGKAWI & 6.33 & 99.73 & 7.0 & 10 Dec 1990 & 13 Dec 2010 & $21 \mathrm{yr}$ \\
\hline 2 & PENANG/BAYAN LEPAS* & 5.30 & 100.27 & 4.0 & 1 Jan 1949 & 13 Dec 2010 & $61 \mathrm{yr}$ \\
\hline 3 & KUALA LUMPUR & 3.10 & 101.70 & 34.0 & 28 Feb 2007 & 6 Mar 2007 & 7 Days \\
\hline 4 & BUTTERWORTH* & 5.47 & 100.38 & 4.0 & 1 Jan 1949 & 13 Dec 2010 & $61 \mathrm{yr}$ \\
\hline 5 & MERSING* & 2.45 & 103.83 & 45.0 & 2 Jan 1949 & 7 Dec 2008 & $60 \mathrm{yr}$ \\
\hline 6 & SULTAN ABDULHALIM & 6.18 & 100.40 & 5.0 & 6 Jul 2004 & 13 Dec 2010 & $6.5 \mathrm{yr}$ \\
\hline 7 & SULTAN AZLANSHAH & 4.57 & 101.08 & 40.0 & $6 \mathrm{Jul} 2004$ & 13 Dec 2010 & $6.5 \mathrm{yr}$ \\
\hline 8 & SULTAN MAHMUD & 5.38 & 103.10 & 7.0 & $6 \mathrm{Jul} 2004$ & 12 Jun 2005 & $1 \mathrm{yr}$ \\
\hline 9 & ALOR STAR $*$ & 6.20 & 100.40 & 5.0 & 1 Jan 1949 & 7 Dec 2008 & $60 \mathrm{yr}$ \\
\hline 10 & CHUPING & 6.48 & 100.27 & 22.0 & 13 May 2004 & 13 May 2004 & 1 Day \\
\hline 11 & KOTA BHARU* & 6.17 & 102.28 & 5.0 & 5 Jan 1949 & 13 Dec 2010 & $60 \mathrm{yr}$ \\
\hline 12 & KUALA KRAI & 5.53 & 102.20 & 65.0 & 21 Aug 1986 & 29 Dec 1986 & 5 months \\
\hline 13 & KUALA TRENGGANU & 5.38 & 103.10 & 6.0 & 12 Oct 2001 & 13 Dec 2010 & $9 \mathrm{yr}$ \\
\hline 14 & KUALA TRENGGANU/CLI & 5.33 & 103.13 & 36.0 & 4 Jan 1949 & 31 Dec 1965 & $16 \mathrm{yr}$ \\
\hline 15 & SITIAWAN* $*$ & 4.22 & 100.70 & 8.0 & 1 Jan 1949 & 13 Dec 2010 & $61 \mathrm{yr}$ \\
\hline 16 & LUBUK MERBAU & 4.80 & 100.90 & 78.0 & 1 Jan 1986 & 31 Dec 2010 & $24 \mathrm{yr}$ \\
\hline 17 & $\mathrm{IPOH}^{*}$ & 4.57 & 101.10 & 40.0 & 1 Jan 1949 & 7 Dec 2008 & $60 \mathrm{yr}$ \\
\hline 18 & CAMERON HIGHLANDS & 4.47 & 101.38 & 1470.0 & 1 Apr 1964 & 31 Dec 1964 & 8 months \\
\hline 19 & CAMERON HIGHLANDS & 4.47 & 101.37 & 1545.0 & 31 Jul 2001 & 7 Dec 2008 & $7 \mathrm{yr}$ \\
\hline 20 & KUALA LIPIS & 4.18 & 102.05 & 169.2 & 1 Jan 1949 & 30 Oct 1953 & $4 \mathrm{yr}$ \\
\hline 21 & BATU EMBUN & 3.97 & 102.35 & 61.0 & 1 Jan 1986 & 31 Dec 2010 & $24 \mathrm{yr}$ \\
\hline 22 & KUALA LUMPUR SUBAND* & 3.12 & 101.55 & 22.0 & 1 Jan 1949 & 13 Dec 2010 & $61 \mathrm{yr}$ \\
\hline 23 & SULTAN ABDULAZIZS & 3.13 & 101.55 & 28.0 & 21 Mar 1999 & 6 Jul 2006 & $7 \mathrm{yr}$ \\
\hline 24 & PANGKOR ISLAND & 4.25 & 100.55 & 1.0 & 1 Jan 1986 & 31 Dec 2010 & $24 \mathrm{yr}$ \\
\hline 25 & PETALING JAYA & 3.10 & 101.65 & 47.0 & 1 Nov 1988 & 15 Jul 2002 & $14 \mathrm{yr}$ \\
\hline 26 & MUADZAM SHAH & 3.05 & 103.08 & 34.0 & 28 Feb 2007 & 5 Mar 2007 & 6 Days \\
\hline 27 & KUALA LUMPUR INTL & 2.72 & 101.70 & 17.0 & 18 Sep 2000 & 13 Dec 2010 & $11 \mathrm{yr}$ \\
\hline 28 & TEMERLOH* & 3.47 & 102.38 & 40.0 & 1 Jan 1949 & 6 Mar 2007 & $59 \mathrm{yr}$ \\
\hline 29 & KUANTAN* & 3.78 & 103.22 & 16.0 & 3 Jan 1949 & 13 Dec 2010 & $61 \mathrm{yr}$ \\
\hline 30 & PORT SWETTENHAM & 3.00 & 101.42 & 3.0 & 1 Jan 1949 & 31 Oct 1953 & $4 \mathrm{yr}$ \\
\hline 31 & MALACCA* & 2.27 & 102.25 & 9.0 & 1 Jan 1949 & 13 Dec 2010 & $61 \mathrm{yr}$ \\
\hline 32 & BATU PAHAT & 1.87 & 102.98 & 7.0 & 1 Jan 1986 & 31 Dec 2010 & $24 \mathrm{yr}$ \\
\hline 33 & KLUANG & 2.02 & 103.32 & 86.0 & 7 Apr 1975 & 13 Apr 1975 & 7 Days \\
\hline 34 & PULAU TIOMAN & 2.82 & 104.17 & 5.0 & 1 Jan 1986 & 31 Dec 2010 & $24 \mathrm{yr}$ \\
\hline 35 & KERTEH & 4.53 & 103.43 & 5.0 & 1 Jan 1986 & 31 Dec 2010 & $24 \mathrm{yr}$ \\
\hline 36 & JOHORE BHARU/SENAI & 1.63 & 103.67 & 40.0 & 1 Jan 1999 & 13 Dec 2010 & $11 \mathrm{yr}$ \\
\hline 37 & WEST MALAYSIA & 6.00 & 100.00 & 361.0 & 1 Jan 1986 & 31 Dec 2010 & $24 \mathrm{yr}$ \\
\hline 38 & WEST MALAYSIA & 6.00 & 102.00 & 12.0 & 1 Jan 1986 & 31 Dec 2010 & $24 \mathrm{yr}$ \\
\hline 39 & WEST MALAYSIA & 5.00 & 102.00 & 12.0 & 1 Jan 1986 & 31 Dec 2010 & $24 \mathrm{yr}$ \\
\hline 40 & WEST MALAYSIA & 4.00 & 101.00 & 60.0 & 1 Jan 1986 & 31 Dec 2010 & $24 \mathrm{yr}$ \\
\hline 41 & WEST MALAYSIA & 4.00 & 102.00 & 12.0 & 1 Jan 1986 & 31 Dec 2010 & $24 \mathrm{yr}$ \\
\hline 42 & WEST MALAYSIA & 4.00 & 103.00 & 28.0 & 1 Jan 1986 & 31 Dec 2010 & $24 \mathrm{yr}$ \\
\hline 43 & WEST MALAYSIA & 3.00 & 102.00 & 12.0 & 1 Jan 1986 & 31 Dec 2010 & $24 \mathrm{yr}$ \\
\hline 44 & WEST MALAYSIA & 3.00 & 103.00 & 28.0 & 1 Jan 1986 & 31 Dec 2010 & $24 \mathrm{yr}$ \\
\hline 45 & EAST MALAYSIA & 2.00 & 112.00 & 172.0 & 1 Jan 1986 & 31 Dec 2010 & $24 \mathrm{yr}$ \\
\hline 46 & EAST MALAYSIA & 2.00 & 113.00 & 241.0 & 1 Jan 1986 & 31 Dec 2010 & $24 \mathrm{yr}$ \\
\hline 47 & EAST MALAYSIA & 3.00 & 113.00 & 241.0 & 1 Jan 1986 & 31 Dec 2010 & $24 \mathrm{yr}$ \\
\hline 48 & EAST MALAYSIA & 3.00 & 114.00 & 425.0 & 1 Jan 1986 & 31 Dec 2010 & $24 \mathrm{yr}$ \\
\hline 49 & EAST MALAYSIA & 3.00 & 115.00 & 217.0 & 1 Jan 1986 & 31 Dec 2010 & $24 \mathrm{yr}$ \\
\hline 50 & EAST MALAYSIA & 4.00 & 114.00 & 425.0 & 1 Jan 1986 & 31 Dec 2010 & $24 \mathrm{yr}$ \\
\hline 51 & EAST MALAYSIA & 4.00 & 115.00 & 217.0 & 1 Jan 1986 & 31 Dec 2010 & $24 \mathrm{yr}$ \\
\hline 52 & EAST MALAYSIA & 5.00 & 116.00 & 94.0 & 1 Jan 1986 & 31 Dec 2010 & $24 \mathrm{yr}$ \\
\hline 53 & EAST MALAYSIA & 5.00 & 117.00 & 21.0 & 1 Jan 1986 & 31 Dec 2010 & $24 \mathrm{yr}$ \\
\hline 54 & EAST MALAYSIA & 5.00 & 118.00 & 4.0 & 1 Jan 1986 & 31 Dec 2010 & $24 \mathrm{yr}$ \\
\hline 55 & EAST MALAYSIA & 2.00 & 114.00 & 425.0 & 1 Jan 1986 & 31 Dec 2010 & $24 \mathrm{yr}$ \\
\hline 56 & EAST MALAYSIA & 6.00 & 116.00 & 94.0 & 1 Jan 1986 & 31 Dec 2010 & $24 \mathrm{yr}$ \\
\hline 57 & EAST MALAYSIA & 6.00 & 117.00 & 21.0 & 1 Jan 1986 & 31 Dec 2010 & $24 \mathrm{yr}$ \\
\hline
\end{tabular}



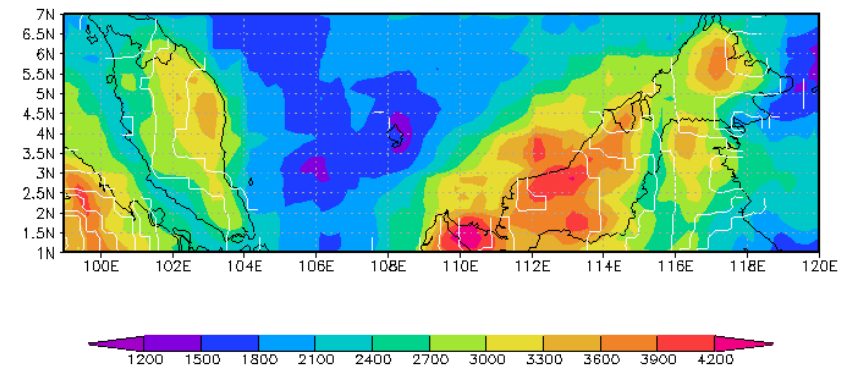

Fig. 2. Coloured areas: TRMM 3B43 V6 accumulated rain (mm); contour: GPCC (mm) climatology for Malaysia (Jan-Dec) 1998 to 2010 .

\section{Validation of TRMM data with the measured ground data}

Rain accumulation data from Global Summary of the Day, NOAA (1949-2010) for 11 stations and GPCC data (19862010) for 57 locations were collected for the validation of TRMM data. The TRMM satellite started its mission on 27 November 1997, therefore NOAA and GPCC data from January 1998 to December 2010 were used to validate the accuracy of the TRMM satellite data with the rain-gauge data in Malaysia; Table 1 shows the list of the stations. Figure 2 show the maps of GPCC rain accumulation compared with the 3B43 data for Malaysia. Figure 3a shows the average monthly rain accumulation (1998-2010) between ground data GPCC and TRMM 3B43 satellite data. The two data agree well between June and October; Figure 3a was retrieved from TRMM online Analysis and Visualization System (TOVAS) website of NASA, USA. Figure $3 \mathrm{~b}$ shows the average monthly percentage error (1998-2010) between ground data GPCC and TRMM 3B43 satellite data for lat 1 to $7^{\circ} \mathrm{N}$. The formula used for the biases between the two data set is given by

Percentage error $=100 \times\left(\frac{\text { GPCC-TRMM3B43 }}{\text { GPCC }}\right)$.

According to this formula, negative percentage error means are overestimated by TRMM 3B43, while positive percentage error means are underestimated by TRMM 3B43. The monthly GPCC ground data agree well with TRMM 3B43 data for lat $1-4^{\circ} \mathrm{N}$ with bias errors between -3.9 and $+13.6 \%$ from January to December. The monthly bias error was large for lat $5-7^{\circ} \mathrm{N}$, with values between -14 and $+52.8 \%$, the highest percentage error (underestimation by TRMM 3B43) occurred between January and March $(+22$ to $+52.8 \%$ ). The minimum monthly biases for all latitude was between April and October $(-14.0$ to $+16.1 \%)$, during the southwest monsoon season. The percentage errors between ground data and satellite data $(-14$ to $+52 \%)$ are expected because we are using $\approx 50 \mathrm{~km}$ by $50 \mathrm{~km}$ TRMM satellite grid average rainfall product compared with ground data, which is just for a single point rain gauge. The two major seasons in

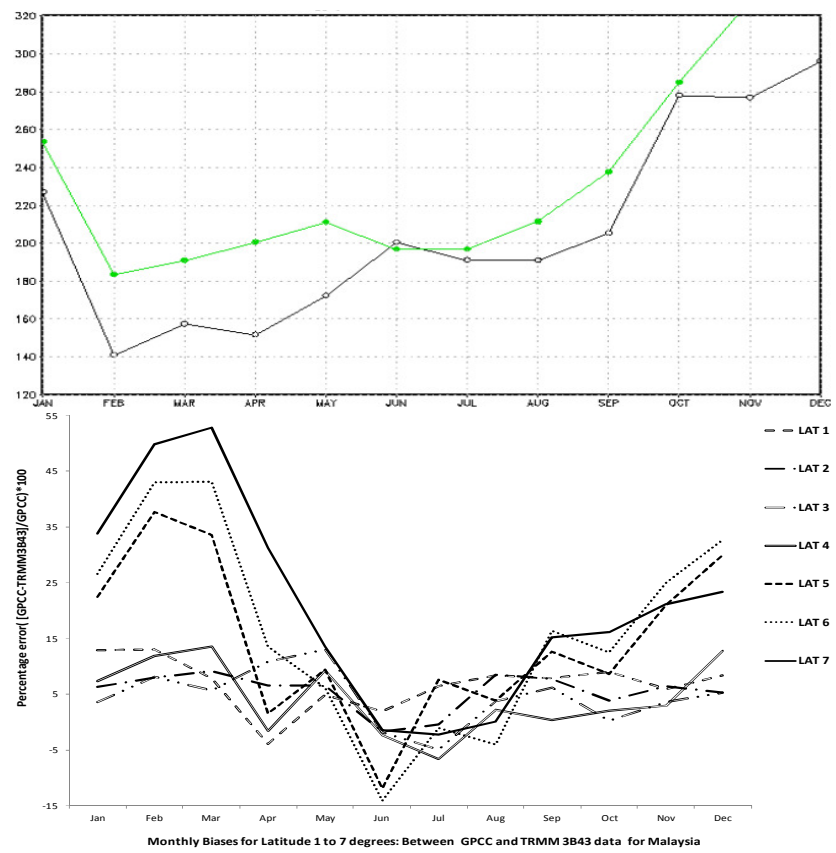

Fig. 3. (a) Comparison between GPCC and TRMM monthly data for Malaysia (Lat: $1^{\circ} \mathrm{N}$ to $7^{\circ} \mathrm{N}$, Lon $99^{\circ} \mathrm{E}$ to $120^{\circ} \mathrm{E}$ ): black TRMM 3B43 V6 accumulated rain ( $\mathrm{mm}$ ) compared with green: GPCC precipitation $(\mathrm{mm})$. (b) Monthly biases error: between GPCC (mm) and TRMM 3B43 V6 accumulated rain (mm), average (Jan-Dec) 1998 to 2010 for Malaysia.

Malaysia are north monsoon that blows from the South China Sea during October to March, and southwest monsoon, blowing from the Straits of Malacca during the months of April to September. Table 3 presents the seasonal rainfall accumulation and seasonal biases of TRMM satellite data with GPCC ground data for each of the 57 locations used in this study. Figure 4 presents the seasonal biases of the TRMM data with increasing latitude $\left(1-7^{\circ} \mathrm{N}\right)$ over the whole of Malaysia. The seasonal bias error is given by

Seasonal bias error $(\mathrm{mm})=($ Seasonal GPCC

-Seasonal TRMM 3B43) accumulation.

Biases for all seasons was minimum for lat $1-4^{\circ} \mathrm{N}(-34$ to $+4 \mathrm{~mm}$ ). Seasonally TRMM biases were minimum for all the latitudes in June, July, and August (JJA), with values from -10.8 to $+12.1 \mathrm{~mm}$.

A previous work on TRMM 3B43 V6 rainfall accumulation (Adeyewa and Nakamura, 2003; Omotosho and Oluwafemi, 2009) have shown similar biases for some tropical locations between January and March. With this fact, it can be considered that the TRMM 3B43 rainfall accumulation is suitable for the estimation of one-minute rainfall rate for the purpose of satellite communication in Malaysia. 
Table 2. Rainfall accumulation retrieval from TRMM 3B43 V6 for Malaysia. Italic states that the rainfall for the specified stations are above $3000 \mathrm{~mm}$.

\begin{tabular}{|c|c|c|c|c|c|c|c|}
\hline & StationName & Latitude & Longitude & Altitude & $\begin{array}{r}\text { Maximum } \\
\text { Monthly }\end{array}$ & $\begin{array}{l}\text { Month with } \\
\text { Maximum }\end{array}$ & $\begin{array}{r}\text { Annual } \\
\text { Mean }\end{array}$ \\
\hline & & $\left({ }^{\circ} \mathrm{E}\right)$ & $\left({ }^{\circ} \mathrm{N}\right)$ & $(\mathrm{m})$ & $\begin{array}{r}\text { Acc in } \\
13 \mathrm{yr}(\mathrm{mm})\end{array}$ & $\begin{array}{l}\text { Acc and } \\
\text { year }\end{array}$ & $\begin{array}{r}\text { Acc for } \\
13 \mathrm{yr}(\mathrm{mm})\end{array}$ \\
\hline 1 & LANGKAWI & 6.33 & 99.73 & 7.0 & 576.7 & Oct 2003 & 2119.9 \\
\hline 2 & PENANG/BAYANLEPAS* & 5.30 & 100.27 & 4.0 & 663.1 & Oct 2003 & 2421.9 \\
\hline 3 & KUALALUMPUR & 3.10 & 101.70 & 34.0 & 489.2 & Nov 2004 & 2884.8 \\
\hline 4 & BUTTERWORTH* & 5.47 & 100.38 & 4.0 & 663.1 & Oct 2003 & 2431.9 \\
\hline 5 & MERSING** & 2.45 & 103.83 & 45.0 & 705.9 & Dec 1998 & 2364.5 \\
\hline 6 & SULTANABDULHALIM & 6.18 & 100.40 & 5.0 & 547.5 & Oct 2003 & 2316.0 \\
\hline 7 & SULTANAZLANSHAH & 4.57 & 101.08 & 40.0 & 468.4 & Oct 2003 & 2557.2 \\
\hline 8 & SULTANMAHMUD & 5.38 & 103.10 & 7.0 & 831.5 & Dec 2008 & 2698.6 \\
\hline 9 & ALORSTAR* & 6.20 & 100.40 & 5.0 & 547.5 & Oct 2003 & 2316.0 \\
\hline 10 & CHUPING & 6.48 & 100.27 & 22.0 & 576.5 & Nov 2000 & 2274.7 \\
\hline 11 & KOTABHARU* & 6.17 & 102.28 & 5.0 & 1405.0 & Nov 2008 & 2694.2 \\
\hline 12 & KUALAKRAI & 5.53 & 102.20 & 65.0 & 1052.8 & Nov 2008 & 3146.1 \\
\hline 13 & KUALATRENGGANU & 5.38 & 103.10 & 6.0 & 1528.7 & Nov 2008 & 3146.1 \\
\hline 14 & KUALATRENGGANU/CLI & 5.33 & 103.13 & 36.0 & 1528.7 & Nov 2008 & 3146.1 \\
\hline 15 & SITIAWAN* & 4.22 & 100.70 & 8.0 & 508.7 & Oct 2003 & 2084.5 \\
\hline 16 & LUBUKMERBAU & 4.80 & 100.90 & 78.0 & 492.6 & Nov 2010 & 2485.6 \\
\hline 17 & $\mathrm{IPOH}^{*}$ & 4.57 & 101.10 & 40.0 & 468.4 & Nov 2003 & 2557.2 \\
\hline 18 & CAMERONHIGHLANDS & 4.47 & 101.38 & 1470.0 & 420.4 & Nov 2005 & 2693.4 \\
\hline 19 & CAMERONHIGHLANDS & 4.47 & 101.37 & 1545.0 & 420.4 & Nov 2005 & 2693.4 \\
\hline 20 & KUALALIPIS & 4.18 & 102.05 & 169.2 & 790.1 & Dec 1998 & 3041.6 \\
\hline 21 & BATUEMBUN & 3.97 & 102.35 & 61.0 & 723.1 & Dec 2007 & 3010.1 \\
\hline 22 & KUALALUMPURSUBAND* & 3.12 & 101.55 & 22.0 & 489.2 & Nov 2004 & 2901.5 \\
\hline 23 & SULTANABDULAZIZS & 3.13 & 101.55 & 28.0 & 489.2 & Nov 2004 & 2901.5 \\
\hline 24 & PANGKORISLAND & 4.25 & 100.55 & 1.0 & 554.0 & Oct 2003 & 2102.5 \\
\hline 25 & PETALINGJAYA & 3.10 & 101.65 & 47.0 & 489.2 & Nov 2004 & 2901.5 \\
\hline 26 & MUADZAMSHAH & 3.05 & 103.08 & 34.0 & 1236.3 & Dec 2007 & 3011.9 \\
\hline 27 & KUALALUMPURINTL & 2.72 & 101.70 & 17.0 & 398.5 & Nov 2003 & 2238.9 \\
\hline 28 & TEMERLOH* & 3.47 & 102.38 & 40.0 & 508.6 & Nov 2005 & 2866.3 \\
\hline 29 & KUANTAN* & 3.78 & 103.22 & 16.0 & 1223.0 & Dec 2001 & 3261.9 \\
\hline 30 & PORTSWETTENHAM & 3.00 & 101.42 & 3.0 & 478.8 & Nov 2004 & 2617.6 \\
\hline 31 & MALACCA* & 2.27 & 102.25 & 9.0 & 325.6 & Nov 2003 & 2329.0 \\
\hline 32 & BATUPAHAT & 1.87 & 102.98 & 7.0 & 534.1 & Dec 2006 & 2478.9 \\
\hline 33 & KLUANG & 2.02 & 103.32 & 86.0 & 848.9 & Dec 2006 & 2956.7 \\
\hline 34 & PULAUTIOMAN & 2.82 & 104.17 & 5.0 & 628.7 & Dec 1998 & 2102.3 \\
\hline 35 & KERTEH & 4.53 & 103.43 & 5.0 & 803.7 & Nov 2009 & 3001.2 \\
\hline 36 & JOHOREBHARU/SENAI & 1.63 & 103.67 & 40.0 & 924.9 & Dec 2006 & 2782.7 \\
\hline 37 & WESTMALAYSIA & 6.00 & 100.00 & 361.0 & 409.2 & Nov 1998 & 2222.9 \\
\hline 38 & WESTMALAYSIA & 6.00 & 102.00 & 12.0 & 1195.3 & Dec 1999 & 2813.1 \\
\hline 39 & WESTMALAYSIA & 5.00 & 102.00 & 12.0 & 930.9 & Dec 2007 & 3230.4 \\
\hline 40 & WESTMALAYSIA & 4.00 & 101.00 & 60.0 & 514.9 & Oct 2008 & 2754.6 \\
\hline 41 & WESTMALAYSIA & 4.00 & 102.00 & 12.0 & 790.1 & Dec 1998 & 3041.6 \\
\hline 42 & WESTMALAYSIA & 4.00 & 103.00 & 28.0 & 749.9 & Dec 2010 & 3313.6 \\
\hline 43 & WESTMALAYSIA & 3.00 & 102.00 & 12.0 & 580.2 & Dec 1998 & 2809.5 \\
\hline 44 & WESTMALAYSIA & 3.00 & 103.00 & 28.0 & 888.6 & Dec 1998 & 3011.9 \\
\hline 45 & EASTMALAYSIA & 2.00 & 112.00 & 172.0 & 603.0 & Dec 2004 & 3808.1 \\
\hline 46 & EASTMALAYSIA & 2.00 & 113.00 & 241.0 & 985.9 & Jan 2009 & 3902.5 \\
\hline 47 & EASTMALAYSIA & 3.00 & 113.00 & 241.0 & 598.6 & Dec 2004 & 3932.7 \\
\hline 48 & EASTMALAYSIA & 3.00 & 114.00 & 425.0 & 725.1 & Jan 2001 & 3640.0 \\
\hline 49 & EASTMALAYSIA & 3.00 & 115.00 & 217.0 & 462.1 & Jan 2001 & 2838.9 \\
\hline 50 & EASTMALAYSIA & 4.00 & 114.00 & 425.0 & 865.9 & Jan 2009 & 3480.8 \\
\hline 51 & EASTMALAYSIA & 4.00 & 115.00 & 217.0 & 583.1 & Jan 2009 & 2967.3 \\
\hline 52 & EASTMALAYSIA & 5.00 & 116.00 & 94.0 & 451.9 & Jan 2009 & 2846.3 \\
\hline 53 & EASTMALAYSIA & 5.00 & 117.00 & 21.0 & 545.8 & Oct 2006 & 3409.4 \\
\hline 54 & EASTMALAYSIA & 5.00 & 118.00 & 4.0 & 468.5 & Dec 2004 & 2727.5 \\
\hline 55 & EASTMALAYSIA & 2.00 & 114.00 & 425.0 & 528.1 & Jan 2009 & 3409.2 \\
\hline 56 & EASTMALAYSIA & 6.00 & 116.00 & 94.0 & 628.1 & Oct 2001 & 2680.2 \\
\hline 57 & EASTMALAYSIA & 6.00 & 117.00 & 21.0 & 980.5 & Jan 2009 & 3606.3 \\
\hline
\end{tabular}


Table 3. Seasonal rainfall accumulation TRMM 3B43 V6, GPCC and mean bias for the 57 stations. Italic states that the rainfall for the specified stations are above $3000 \mathrm{~mm}$.

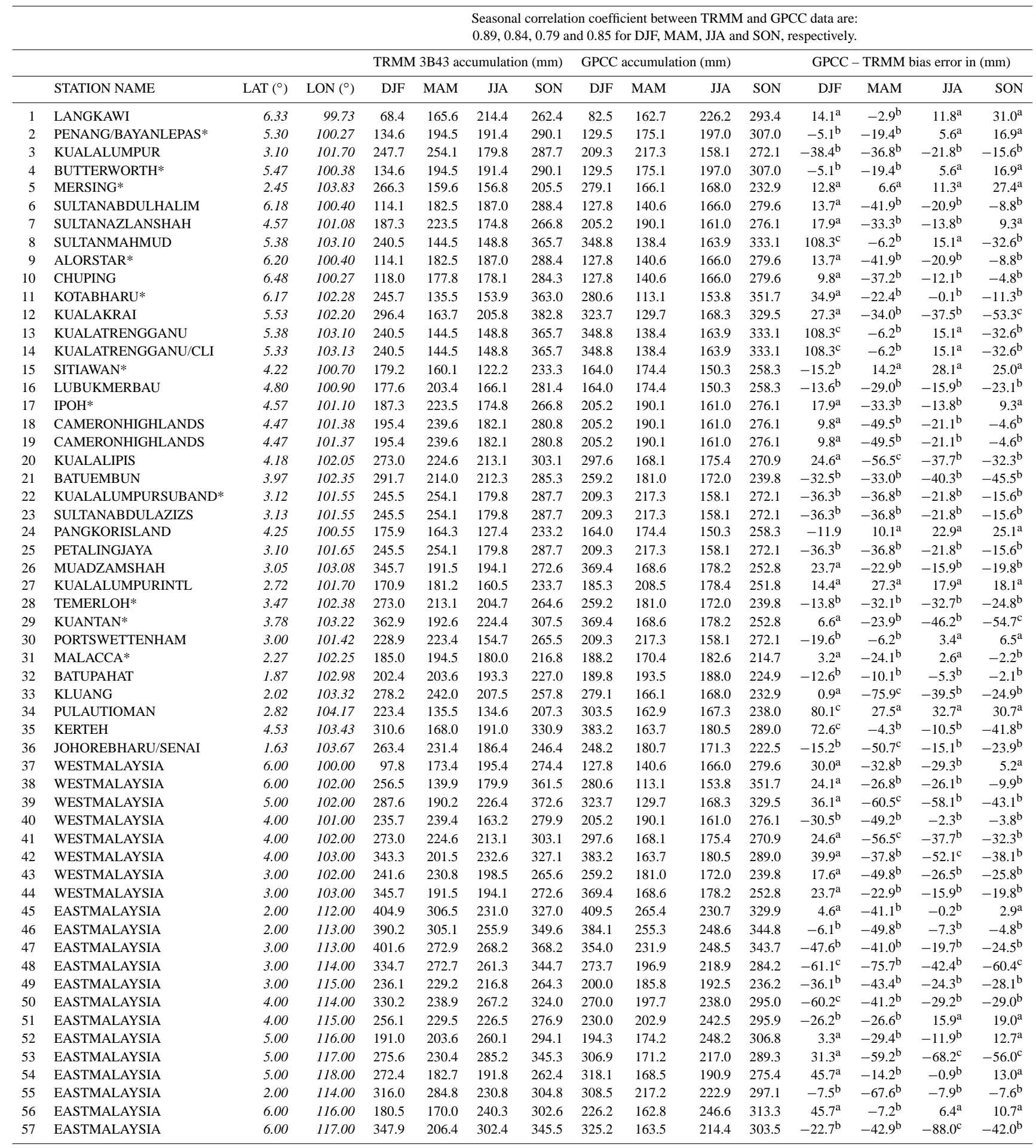

a $\%$ of underestimation by TRMM satellite $=31.1 \%$; $\%$ of overestimation bY TRMM satellite $=68.8 \%$; $\%$ of TRMM biases that is $> \pm 50 \mathrm{~mm}=0.1 \%$. 


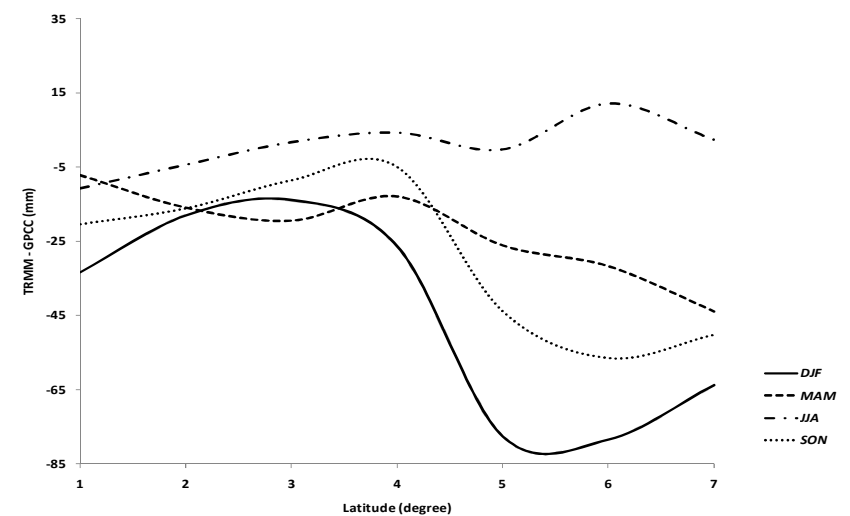

Fig. 4. Seasonal biases of TRMM data with increasing latitude $\left(1^{\circ} \mathrm{N}\right.$ to $\left.7^{\circ} \mathrm{N}\right)$ over Malaysia.

\subsection{Selection of a suitable rain rate prediction model and data processing}

Owing to lack of high-temporal-resolution data in eastern Malaysia (EM) and western Malaysia (WM), the approach selected to calculate one-minute point rain rate for the 57 locations was to use complementary cumulative distribution function using prediction models. Long-term data, such as monthly accumulation, average yearly accumulation, thunderstorm ratio, etc., accepted as input to various models, have been proposed for the prediction of one-minute point rain rate cumulative distribution, based on long-term data, such as those of Rice and Holmberg (1973), Tattelman and Mazzella (1995), Chieko and Yoshio (2002). In the modeling for tropical regions, Moupfouma and Martin (1993) proposed a distribution function that has been tested by Ajayi (1996) in Nigeria as well as Chebil and Rahman (1999) and Mandeep and Syed (2004) in Malaysia. More recently, Emiliani et al. (2009) found that the model developed by Chieko and Yoshio (2002) gives the best prediction accuracy among all the current models and is suitable for worldwide application, especially for small percentage of time (0.001-1\%), which is important for radio system design. This is because it incorporates the thunderstorm ratio, $\beta$, as a meteorological input.

Therefore, the Chieko and Yoshio (2002) model was used to estimate the one-minute point rain rate for Malaysia. For ease of data analyses in this work, the 57 stations in Fig. 1 were divided into two distinct regions, namely, WM and EM. For each of the 57 stations, the thunderstorm ratio $\beta$ was calculated using the TRMM satellite convective and stratiform rain rate accumulation data (3A12) from TRMM Microwave Imager sensor. The model divided the rainfall into two types to permit the prediction of rainfall rate statistic from the total rainfall accumulation measured in an average year. The two types were termed as mode 1 rain $(M 1)$ and mode 2 rain (M2). M1 contained the high rainfall rates associated with strong convective activity and thunderstorms. $M 2$ was simply everything else. Thus, the total average rainfall accumulation

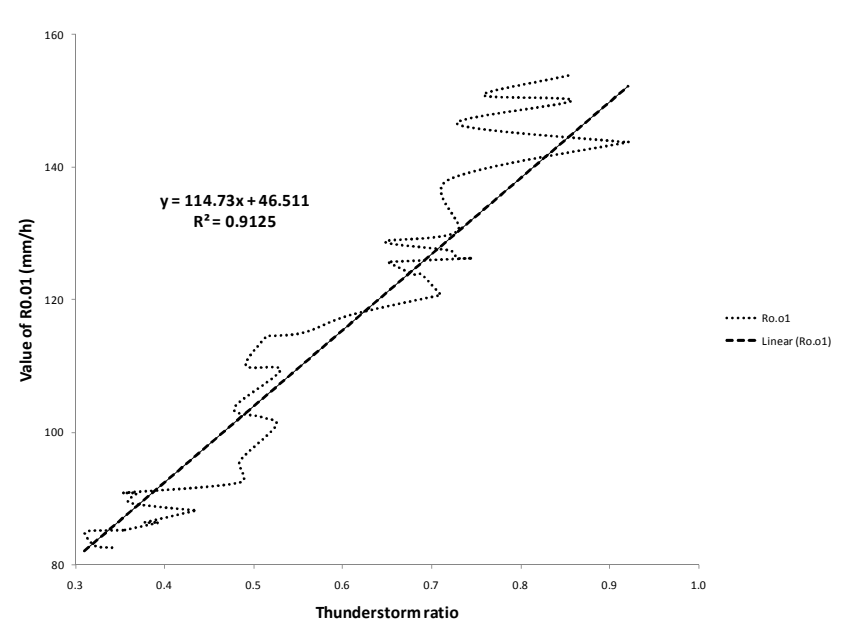

Fig. 5. A sensitivity analysis of the impact of the variation of $\beta$ on the predicted $R_{0.01 \%}$ for the 57 stations in Malaysia.

$M$ can be calculated as

$M=M 1+M 2(\mathrm{~mm})$.

The ratio of thunderstorm rain accumulation to the total rainfall accumulation can be given as

$\beta=M 1 / M$.

the Chieko and Yoshio (2002) model for arbitrary percentage of time $P(\%)$ and $R_{\mathrm{p}}\left(\mathrm{mm} \mathrm{h}^{-1}\right)$ can be estimated by using only the average annual total rainfall and the thunderstorm ratio. The model is given by Eqs. (4)-(7) using coefficients $a_{\mathrm{p}}, b_{\mathrm{p}}, c_{\mathrm{p}}$ with $x=\log (p)$. These equations were determined by multiple regression analyses of a databank of rain attenuation on satellite links of 290 data sets from 84 locations in 30 countries, and a databank of different integration time rain rates, which contains data sets from 54 locations in 23 countries.

$$
\begin{aligned}
& R_{\mathrm{P}}=a_{\mathrm{p}} M^{b_{\mathrm{p}}} \beta^{c_{\mathrm{p}}} \\
& \log \left(a_{\mathrm{p}}\right)=0.1574155 x^{4}+1.348171 x^{3}+3.528175 x^{2} \\
& +1.479566 x-2.302276 \\
& b_{\mathrm{p}}=-4.583266 \times 10^{-2} x^{4}-0.4098161 x^{3}-1.162387 x^{2} \\
& -0.8261178 x+0.911857 \\
& c_{\mathrm{p}}=2.574688 \times 10^{-2} x^{4}+0.1549031 x^{3}+0.1747827 x^{2} \\
& -0.2846313 x+1.255081 \times 10^{-2}
\end{aligned}
$$

For the computation of the derived one-minute rainfall rates, a program named Rain rate was developed in Matlab, which can be considered as a function in Microsoft Excel, taking into consideration the three major input parameters, namely, 

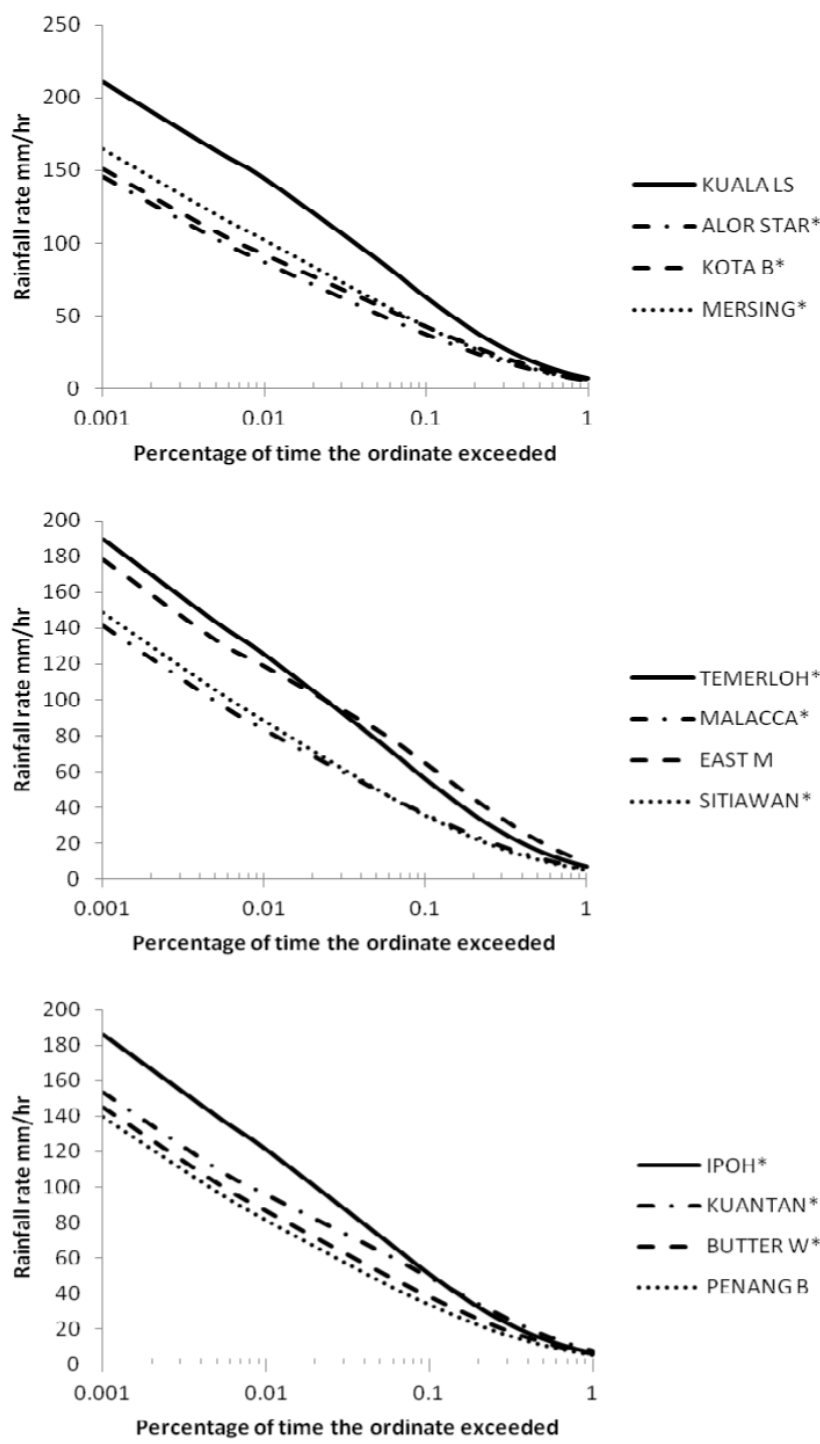

Fig. 6. Cumulative distributions of rainfall rates for the 12 selected stations in Malaysia.

the annual rainfall accumulation $M$ in mm, thunderstorm ratio $\beta$, and percentage of time unavailability $P$ in \% (Omotosho, 2010). Table 2 presents the annual average rain accumulation, month with maximum accumulation, and maximum monthly accumulation in 13 yr. October (11 stations), November (19 stations), December (19 stations) and January (8 stations) are the months with maximum accumulation for all 57 locations in Malaysia. Months with maximum accumulation are the worst months associated with the high rainfall rate. Table 3 shows the seasonal accumulation and bias error between TRMM and GPCC for each of the 57 locations. The seasonal bias errors are important and will provide extra information regarding the uncertainty of satellite-based estimation for each station. Figure 5 also shows the sensitivity analysis of the impact of the variation of the thunderstorm ratio $\beta$

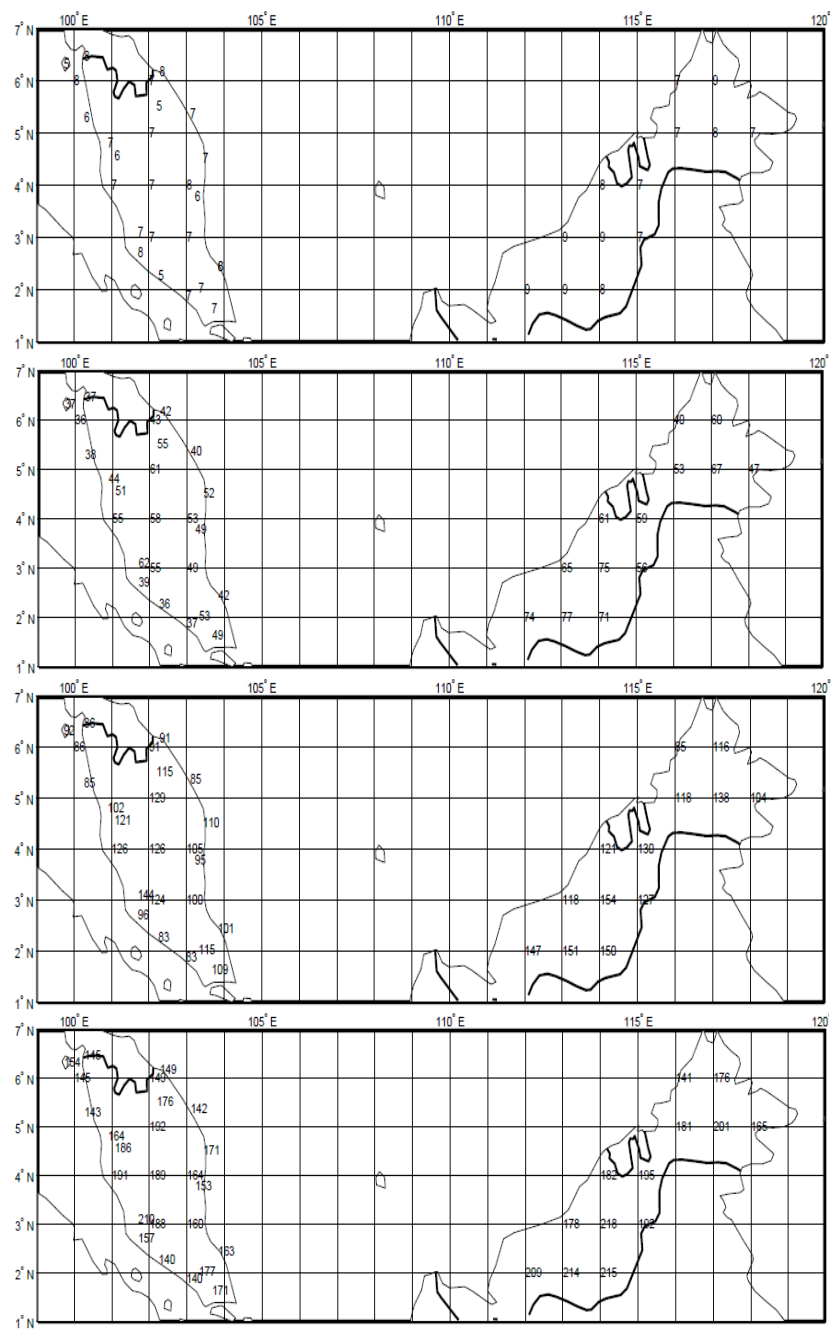

Fig. 7. (a) One minute rain rate $\left(\mathrm{mm} \mathrm{h}^{-1}\right)$ exceeded for $1 \%$ of time for system design in Malaysia. (b) One minute rain rate $\left(\mathrm{mm} \mathrm{h}^{-1}\right)$ exceeded for $0.1 \%$ of time for system design in Malaysia. (c) One minute rain rate $\left(\mathrm{mm} \mathrm{h}^{-1}\right)$ exceeded for $0.01 \%$ of time for system design in Malaysia. (d) One minute rain rate $\left(\mathrm{mm} \mathrm{h}^{-1}\right)$ exceeded for $0.001 \%$ of time for system design in Malaysia.

on the predicted one-minute rain rate, $R_{0.01 \%}$ for Malaysia. The thunderstorm ratio $\beta$ increases linearly with rainfall rate $\left(R_{0.01 \%}\right)$, hence the linear fit can be use to evaluate rainfall rate for any location in Malaysia if the thunderstorm ratio is available for that location. Figure 7a-d shows the map of the predicted one-minute point rain rate unavailability for 1 to $0.001 \%$ in an average years.

\section{Results and discussion}

The rainfall accumulation data (for $13 \mathrm{yr}$ ) retrieved from TRMM satellite (Table 2) revealed that the annual rainfall accumulation in WM and EM was between 2102.3 and $3932.7 \mathrm{~mm}$, with EM having the highest rainfall 


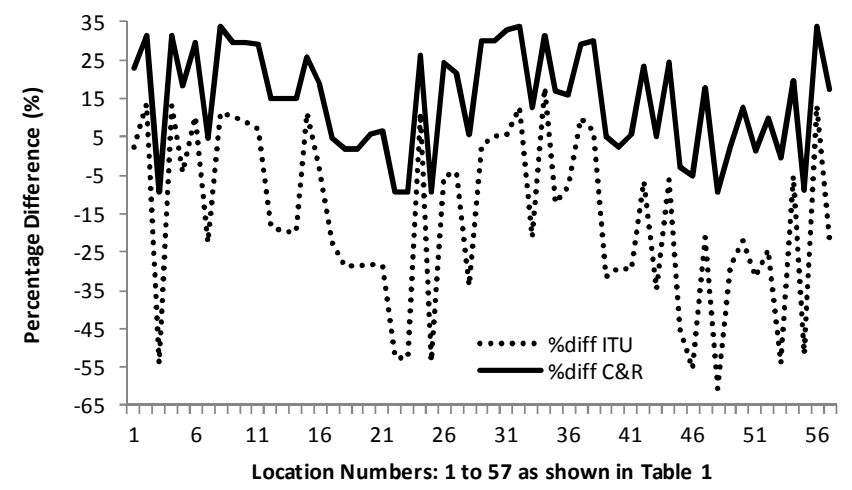

Fig. 8. Comparison of the present work with ITU and Chebil and Rahman (C\&R) data; the correlation coefficient for C\&R (0.7) and for ITU (0.01).

accumulation of $3932.7 \mathrm{~mm}$. Twenty locations out of the 57 stations were found to have an annual rainfall accumulation of $>3000 \mathrm{~mm}$, with the following distribution: 12 out of 44 stations in WM and 8 out 13 locations in EM were found to have an accumulation of $>3000 \mathrm{~mm}$. Furthermore, the satellite revealed that the maximum monthly accumulation (and the year of occurrence) in $13 \mathrm{yr}$ was between 325.6 and $1528.7 \mathrm{~mm}$. It was also revealed that they occurred between October and December in WM, and between December and January in EM. Table 2 shows 7 locations in WM with monthly accumulation $>1000 \mathrm{~mm}$, namely, Kota Bharu, Kuala Krai, Kuala Trengganu, Kuala Trengganu/Cli, Muadzam Shah, and Kuantan; a high rainfall rate is likely to occur between November and December.

Figure $7 \mathrm{a}-\mathrm{d}$ presents the results of the estimated rain rate exceedance from 0.001 to $1 \%$ in an average year, which is of interest for satellite communication system design. It can be observed from the map that a higher rainfall rate occurred in EM than WM. In WM, for 44 stations, the rain rate was found to be between 81.8 and $143.8 \mathrm{~mm} \mathrm{~h}^{-1}$, while for 13 stations in EM, the rain rate was observed to be between 84.7 and $153.9 \mathrm{~mm} \mathrm{~h}^{-1}$ for $0.01 \%$ exceedance. For exceedances of $0.001,0.1$, and $1 \%$, the values were $140.0-218.0,33.6-$ 77.0 , and $5.2-9 \mathrm{~mm} \mathrm{~h}^{-1}$, respectively, for all the 57 locations. Figure 6 presents the cumulative distribution of the rainfall rate for the twelve selected stations. Figure 8 shows the comparison of this present work with other available results for Malaysia, such as ITU-RP SG3 database (2009) and the results obtained by Chebil and Rahman (1999), which only covered WM. However, the method and the data used to estimate the one-minute point rain rate in this present work make a direct comparison very difficult. The present work is based on TRMM satellite data, while the work of Moupfouma et al. (1990) and Yusof et al. (1990) is based on ground data at a few locations, extrapolated and gridded for other surrounding locations. The present work agrees well with the work carried out by Chebil and Rahman (1999), with a correlation coefficient of 0.7, rather than the ITU-RP SG3 database (2009) correlation coefficient of 0.01 . In this work, for $0.01 \%$ exceedance, $R_{0.01}$ was from 82 to $154 \mathrm{~mm} \mathrm{~h}^{-1}$, lowest in WM and highest in EM. Chebil and Rahman (1999) found that $R_{0.01}$ was from 119 to $144 \mathrm{~mm} \mathrm{~h}^{-1}$ in WM. For the ITU-RP SG3 database, the $R_{0.01}$ was from 87 to $101 \mathrm{~mm} \mathrm{~h}^{-1}$, lowest in WM and highest in EM. This present work is the only work that has covered both WM and EM using satellite data validated with ground data. Overall, the correlation coefficient of this work with ITU-RP SG3 is very poor, while the present results agree well with the study carried out by Chebil and Rahman (1999).

\section{Summary and conclusions}

This work presents new point rain rate data derived from TRMM satellite rainfall data for microwave system design in WM and EM. This was validated with different ground data sources from NOAA, GPCC, and NASA. Building on previous studies in the region, a model has been used that gives the best prediction accuracy of one-minute rainfall rate cumulative distribution functions for any location for which the measured data are not available. Monthly accumulation, annual rainfall accumulation, and thunderstorm ratio have been retrieved from TRMM 3B43 and 3A12 (1998-2010), and have been used to estimate one-minute rain rate statistics for 57 locations in the Malaysian region for $0.001-1 \%$ of the time. The results show that the present work agrees well with the previous work carried out by Chebil and Rahman (1999), while the ITU-R SG3 database (2009) prediction for $R_{0.01}$ is found to be valid for limited areas in Malaysia and underestimates the remaining regions. Another interesting result is the new set of thunderstorm ratio (for Malaysia) derived from the TRMM satellite, which is one of the input parameters required by most of the models converting the annual rainfall accumulation to one-minute rain rate for use in the design of both terrestrial and earth-space satellite microwave radio communication.

Acknowledgements. The authors would like to thank Universiti Kebangsaan Malaysia, Institute of Space Science.

Topical Editor P. Drobinski thanks E. I. Nikolopoulos and one anonymous referee for their help in evaluating this paper.

\section{References}

Adeyewa, Z. D. and Nakamura, K.: Validation of TRMM radar data over major climatic regions in Africa, J. Appl. Meteorol., 42, 331-347, 2003.

Ajayi G. O. (Ed.): Handbook on Radio-propagation Related to Satellite Communication in Tropical and Subtropical Countries, Triesty, Italy, URSI Standing Committe on Developing Countries, International Centre for Theoretical Physics, 1996. 
Anagnostou, E. N., Krajewski, W. F., and Smith, J. A.: Uncertainty quantification of mean-areal radar-rainfall estimates, J. Atmos. Ocean. Technol., 16, 206-215, 1999a.

Anagnostou, E. N., Negri, A. J., and Adler, R. F.: Statistical adjustment of satellitemicrowave monthly rainfall estimates over Amazonia, J. Appl. Meteorol., 38, 1590-1598, 1999 b.

Barrett, E. C., Doodge, J., Goodman, M., Janowiak, J., Smith, E., and Kidd, C.: The First WetNet precipitation intercomparison project (PIP-1), Remote Sens. Rev., 11,49-60, 1994.

Bell, T. L., Abdullah, A., Martin, R. L., and North, G. R.: Sampling errors for satellite derived tropical rainfall: Monte Carlo study using a space-time stochastic model, J. Geophys. Res., 95, 2195 2206, 1990.

Chang, A. T. C. and Chiu, L. S.: Nonsystematic errors of monthly oceanic rainfall derived from SSMI, Mon. Weather Rev., 127, 1630-1638, 1999.

Cheibil, J. and Rahman, T. A.: Rain rate Statistics Conversion for the Prediction of Rain Attenuation in Malaysia Electronics Letters, 35, 1019-1021, 1999.

Chieko, I. and Yoshio, H.: The thunderstorm ratio as a regional climatic parameter: its effects on different-integration-time rain rate conversion, rain attenuation, site-diversity and rain depolarization, in: Proceedings of URSI 2002, GA02 paper P0181, 2002.

Chiu, L. S., Short, A., McConnel, A., and North, G. R.: 1990. Rain estimation from satellites: effect of finite field of view, J. Geophys. Res., 95, 2177-2185, 1990.

Chiu, L. S., Ha, E., and North, G. R.: Error analysis for some ground validation designs for satellite observations of precipitation, $\mathrm{J}$. Atmos. Oceanic Technol., 16, 149- 1957, 1999.

Emiliani, L. D., Luni, L., and Capsoni, C.: Analysis and Parameterization of Methodologies for the conversion of Rain-Rate $\mathrm{Cu}$ mulative Distribution from various Intergration Times to One minute, IEEE Antennas and Propagation Magazine, 51, 70-84, 2009.

Huffman, G. J., Alder, R. F., Rudolf, B., Schneider, U., and Keehn, P. R.: Global precipitation estimates based on a technique for combining satellite-based estimates, rain gauge analysis, and NWP model information, J. Climate, 8, 1284-1295, 1995.

Huffman, G. J.: Estimates of root-mean-square random error for finite samples of estimates precipitation, J. Appl. Meteorol., 36, 1191-1201, 1997.

Kousky, V. E.: Diurnal rainfall variation in north-east Brazil, ITURP 2009 Study Group 3 data base, Mon. Weather Rev., 108, 488498, 1980

Kummerow, C.: Beam filling errors in passive microwave rainfall retrievals, J. Appl. Meteorol., 37, 356-357, 1998.

Mandeep J. S. and Syed, I.:Comparison of One Minute Rainfall Rate Distributions for Tropical and Equitorial Climates Space Communications, 19, 193-198, 2004.

Moupfouma, F., Martin, M., Spanjaard, N., and Hughes, K.. Rainfall rate characteristics for microwave system in tropical and equatorial areas, Int. J. Satell. Commun., 8, 151-161, 1990.

Moupfouma, F. and Martin, L.: Point Rainfall Rate Cumulative Distribution Function Valid at various Locations Electronics Letters, 29, 1503-1505, 1993.
NOAA Global Summary of the Day, available at: ftp://ftp.ncdc. noaa.gov/pub/data/gsod/ (last access: 8 January 2011), 2011.

Nirala, M. L. and Cracknell, A. P.: The determination of the three distribution of rain from the Tropical Rainfall Measuring Mission (TRMM) Precipitation Radar, Int. J. Remote Sens., 23, 42634304, 2002.

Ojo, J. S., and Omotosho, T. V.: Comparison of 1-min rain rate derived from TRMM satellite data and raingauge data for microwave applications in Nigeria, J. Atmos. Sol.-Terr. Phy., 102, 17-25, 2013.

Omotosho, T. V.: Studies of Propagation Impairments on Earth Space Path For Fixed Satellite links at Microwave Frequencies in Nigeria, ISBN:978-3-8433-7131-5 LAP LAMBERT Academic publishing GmbH \& Co. KG and licensors, 2010.

Omotosho, T. V. and Oluwafemi, C. O.: Impairment of radio wave signal by rainfall on fixed satellite service on Earth space path at 37 stations in Nigeria, J. Atmos. Sol.-Terr. Phy., 71, 830-840, doi:10.1016/j.jastp.2009.03.016, 2009.

Rice, P. L. and Holmberg, N. R.: Cumulative time statistics of surface-point rainfall rates, IEEE Trans. Com, 21, 1131-1136, 1973.

Rudolf, B., Hauschild, H., Rueth, W., and Schneider, U.: Terrestrial precipitation analysis: operational method and required density of point measurement, in: Global Precipitations and Climate Change, edited by: Debois, M. and Desalmand, F., 26, NATO, ASI Series 1, 1994.

Simpson, J., Kummerow, C., Tao, W. K., and Adler, R. F.: On the tropical rainfall measuring mission (TRMM), Meteorol. Atmos. Phys. 60, 19-36, 1996.

Tanvir, I., Miguel, A. R. R., Dawei, H., Pranshant, K. S., and Ansor, M. I.: Performance evaluation of the TRMM precipitation estimation using ground-based radars from the GPM validation network, J. Atmos. Sol-Terr. Phy., 77, 194-208, 2012.

Tattelman, P. L. K. and Mazzella, A.: "A Climatological Model for 1-min Precipitation Rates”, J. Appl. Meteorol., 34, 1020-1027, 5 May, 1995.

TRMM Satellite Validation Office: available at :http://trmm-.gsfc. nasa.gov/trmm.gv/index.shtml (last access: 8 January 2011), 2011.

TRMM website: available at :http://disc2.nascom.nasa.gov/ Giovanni/tovas/, July, 2013a.

TRMM website 2: available at :http://rain.atmos.colostate.edu/ CRDC/datasets/trmm.html, August, 2013b.

Xie, P. and Arkin, P. A.: An intercomparison of gauge observation and Satellite estimate of monthly precipitation, J. Appl. Meteorol., 34, 1143-1160, 1995.

Xie, P. and Arkin, P. A.: Analyses of global monthly precipitation using gauge observations, satellite estimates, and numerical model predictions, J. Climate, 9, 840-858, 1996.

Yusof, M. A., Mohd, M., and Hassan, S. I.: Recommended conversion factors for Malaysian based on one year measured rainfall data, in: Proceedings of URSI Commission F Open Symposium on Regional Factors in Predicting Radio Wave Attenuation due to Rain, Rio de Janeiro, Brazil, 47-52, 1990. 